\title{
Religious Language: Problems and Meaning
}

\author{
Emeka Ugwueye \& Ngozi Ezenwa-Ohaeto \\ DOI: http://dx.doi.org/10.4314/ujah.v12i1.11
}

\section{Abstract}

This paper examines religious language by $x$-raying both its meaning and the associated problems. The paper also looked at the relationship between language and religion. It argues that, inasmuch as there are identified problems with religious language, it has helped in understanding religious experiences which make belief or faith to be a reality. Therefore, the expression of Religious Language which essentially contains predicate about God and His nature, also have or show some meanings at least to the group of people who use such language. This paper concludes that Religious language communicates and expresses ideas, emotions and convictions to faith audience. It is the medium for the transmission of religious ideas between faith members. The end purpose of this expression and communication of religious ideas and emotions is to elicit acts that are similar to what is expressed and communicated in order to enjoy both religious communal body and life hereafter.

\section{Introduction}

"Language is the expression and communication of emotions, ideas or thoughts between human beings by means of speech and hearing. It refers to the sounds spoken and heard being systematized and confirmed by usage among a given people over a period of time "(Stephenson, Voorhees and Morris 716). Using these vocabularies and phraseologies, religious beliefs were transferred and retained from generation to generation within the body of oral literature, the spoken tradition of a society. "This tradition continues, but since the invention of writing, the oral religious tradition has been 
supplemented by the perpetuation of religious information in the form of sacred religious texts to commentaries on them" (Crapo 146).

Scientific and archeological discoveries are expressed in language, political and historical thoughts are expressed in language. Every kind of idea or feeling is given through the medium of language. Most natural, religious ideas are also represented in language. As a result, religion has developed its own register and consequently it has generated some peculiar "text-variety" (Bhatia 6). The effect is that any single religious organization forms a speech community with its own "vocabulary pronunciation and phraseology which are not generally used or even known throughout the border community". (Coupland and Jaworsky 165)

Once a language becomes associated, with religious worship, its believers often ascribe virtues to the language of worship that they would not give to other language even their native tongues. Religious or sacred language is vested with a solemnity and dignity that ordinary languages lack. Consequently, the training of priests in the use of religious language becomes an important cultural investment, and the use of the language is perceived to give them access to a body of knowledge that untrained lay people cannot have. The sacred languages typically preserve characteristics that would have been lost in the course of language development. In some cases, the religious language is a dead language. In other cases, it may simply reflect archaic forms of a living language.

Some $17^{\text {th }}$ century elements of the English languages, for instance, remain current in protestant Christian worship through the use of the King James Bible or older Versions of the Anglican Book of Common Prayer. In more extreme cases, the language of the liturgy is no longer comprehensible without special training. In some instances, the sacred 
language may not even be or have been native to a local population, that is, missionaries or pilgrims may carry the religious language to people who never spoke it, and to whom it is altogether alien language.

A number of languages have been used as religious languages. They include: classical Arabic for Muslims who believe it to be the only language of the Qur'an. It differs from the various forms of contemporary spoken Arabic. The core of the Hebrew Bible is written in classical Hebrew referred to by some Jews as the "Holy language". Hinduism is traditionally considered to have one liturgical language Sanskrit. The churches which trace their origin to the apostles have continued to use the standard languages of the few centuries after Christ's Ascension. These include; Latin in the Catholic Church, Greek in the Greek Orthodox Church and Greek Catholic church, Coptic in the Coptic Orthodox Church and Syriac in the Syriac churches (Buswell 137).

Beside sacred languages, there are phrases or statements that could be labeled as religious sayings. Having a conversation about the cost of things in the market or about poverty in the society is nothing unusual. Each is a topic directly related to everyday experience and we often refer to them as everyday language. If the conversation was to turn to discussion about God or Virgin Mary or Angels, then the language drifts from the everyday to the religious, mysterious, sacred or metaphysical. Many doubt the truth of such statements yet they are said often.

It is within the purview of this paper to discuss the relationship between language and religion with a view to understand the meaning and problem of religious language. 


\section{Relationship between Language and Religion}

Some elements of relationship exist between language and religion. Acquiring a religion involves to some extent learning a new vocabulary and syntax. It would be impossible to acquire a religion without the medium of language. Because what is said may particularly condition what can be thought, the use of such speech pattern will have subtle psychological effects on the speakers, tending to limit what can be named and hence what can be thought. Hence, religion and language are closely connected to each other.

The tie that exists between language and religion is such that enables language to be used for intra-group communication within religious settings. In this context, language functions to help maintain conformity to religious values, beliefs and ritual practices. "Religious jargons that are uncommon outside a religious group may be expressed, syntax may become more formal or even archaic, and style of speaking- such as a particular cadence, resonance and intonation pattern that is characteristic of the group- may be adopted. The underlying message communicated by these is "We are a unified group with common religious values and belief" (74).

A typical example of an in-group linguistic identity is the phenomena of Glossolalia (Speaking in tongues). This is "the production of sound sequences that have no conventional meanings in speech like acts) Crapo (160) which often occurs during ecstatic trance states. In Nigeria for instance, glossolalia is commonly associated with Pentecostals churches where it is understood as "a gift of the Spirit" in which the speaker is believed to be either praising God in angelic language or is into a spiritual war-fare. In the later, the common belief amongst the members of the Pentecostal churches is that glossolalia often confuses or throws the devil off balance. 
Many religions have a sacred language and because religions are ancient in origin, the languages they use are often particularly or wholly unintelligible to the laity. According to Freeman, attempts to bring the language up to date often coincidence with a loss of religious faith. Many Roman Catholics lament the abandonment of the Latin Mass in favour of the vernacular, and disuse of the Book of Common Prayer by the Church of England has not prompted an influx of young worshippers to the church.

Religion is seemingly universal in all human societies. Although religions may vary greatly from one society to another, they posses certain feature in common as to warrant their being labeled religions. Many people have interpreted their universality and similarity as indicating the presence of a religious belief and practice in all human beings. In the same vein, every human society possesses a language. Chomsky in Campbell has famously claimed that there are similarities in the structures of all languages that point to the existence of a "universal Grammar" or "deep structure".

The grammar or deep structure of human languages is very complex, yet young children seem to have an innate ability to master this complexity within a short time. In fact......noted that by the time a child is.....The language ability of children therefore is different from that of adult. Any adult who has tried to learn a new language can testify to this. Religion, like language, has evolved to be easily learned too by children. Religion is acquired by children in a very similar way like language. Many people are taught religion literally at their mother's knees, and religions infused early in life in this way have a different lasting effect from those adopted later as a result of conversion. Religious beliefs inculcated in childhood are also difficult to shake off, just as 
one's mother tongue (L1) is more persistence in the face of disuse than languages learned in later life (L2).

Deacon argued sometime that languages could be thought of as parasites or viruses to their hosts. The same view is held about religion by many. But it is proper to see them as symbiotic as both are beneficial to their hosts. We cannot do without language in any society, the fact that it could be exploited for evil notwithstanding. This is also true of religion. As we contemplate the spread of fundamentalism and fanaticism today among many religions, with all that this portends for continuing conflict and perhaps the disintegration of society, it is difficult to avoid a sense of helplessness. Religion is so deeply interfused in our mental make-up that most of us cannot do without it. In helpless moments, our outlook may be bleak without it. Be that as it may, language, just like religion, can be beneficial or harmful or even neutral.

Languages are not static but evolved over time; they behave in fact like living organisms. The same is true of religion. As rules a language passes from generation to generation, the vocabulary and syntactical rules tend to get modified by other languages. Eventually words, phraseology and syntax will diverge so radically that people will find it impossible to mix elements of both without confusion. By analogy to biological evolution, different lineages of a common ancestral language will diverge so far from each as to become reproductively incompatible.

Religion has exact description a Christianity for instance evolved Judaism but, they have both become different species, which can no longer interbreed. The same thing is found in Christianity itself and other world religions.

Language and religion are related in the sense of uniting their users. People who speak the same tongue are likely to be closer and friendlier than others who do not 
understand the language of communication. This is seen clearly where people of diverse dialects converge in a place. Religion has such a binding force among its votaries that sometimes supersede that of siblings. In fact, some Christian conservatives and Christian denominations address one another as 'brother', 'sister' or even 'elder'.

In the same manner, language and religion, individually or collectively, can be strong determining factors for employment, admission into schools, marriage and a whole lot of other cooperation, unions and solidarities. In Nigeria, for instance, it is difficult for one of these two factors or both not to be exhibited before any meaningful considerations is taken in most aspects of our lives. Besides that language and religion relate positively, they also possess, by their nature, the capacities to be exploited for negative purposes. Manipulators of language and religion have used them in the past for the destruction of many lives. Language and religion can successfully be used to hide the truth from the people. They could be employed to cause confusion, disunity and war in the society. At no time is this achieved better other than when religious emotions or convictions are expressed through the language of the people by trusted "experts". This is the power of religion and language. Most of the religious upheavals we have had in this country came to be through this way. To understand religious language which falls under what Crapo (156) calls 'restricted code' is not easily decoded especially if one is not an insider. Even insiders or 'believers 'do not always understand some aspects religious language as they the regular one.

\section{Problems of Religious Language}

One major observable problem with religious language lies with the phenomenon of language change. Language change/shift can make traditional language incomprehensible 
to the later ages. So also the change in the meanings of the religious expressions which can be obvious not minding the retaining of the meaningfulness of the statements but now a different meaning from its original denotation. In such situations, the later generations may be unaware that their understanding of a religious text might be quite different from that of their forebears. Citing Crapo's instances in the King's James translation of 2 Thessalonians 5:22 "Abstain from all appearance of evil", the word 'appearance' was intended to signify "to come to view". Thus, the admonition meant "avoid evil when first appears". Crapo further observes that "to $21^{\text {st }}$ century readers however, the English sentence still seems quite 'outward semblance of' and to mistake the meaning of the sentence as "don't even behave in a way that might appear evil" (174-75).

Another instance of change in meaning can be found in 2 Thessallonians2:7." For the mystery of iniquity doth already work; only he who now letteth will let, until he be taken out of the way", where 'let' meant 'to restrain or prevent' in the 1600 s but now means of permit. A more contemporary rendering is found in the New Revised Standard Version: "For the mystery of lawlessness is already at work, but only until the one who now restrains it is removed. Or when the king James translators chose "Peculiar" to describe the Hebrew people (Deuteronomy 14:2), the word meant "private property [of God]", while the modern reader would more likely think that such verses indicated that they were in some way strange. Various verses (such as Mathew 13:12; Mark 6:25; and Luke 21:9) in which the king James English used the phrase "by and by" are likely to be misunderstood today to mean "eventually", whereas to the reader in the 1600 s, the phrase had nearly the opposite meaning of "immediately" (Crapo 175). 
On the other hand, The Encyclopedia of Philosophy online refers to the term "religious language" as statement of claims made about God or gods. If God is infinite, then words used to describe finite creatures might not adequately describe Him. Some of these statements are religious statements: god is good", "God is merciful", "Angels are on guard", "God said, kill all Amalekites", "Holy Ghost fire pursue them' etc. The questions might be: is God good in the same sense as Obama is good? Is God merciful in the same sense as Mother Theresa was .Are Angels on guard in the same way security men guard a place? Did God ask the Israelites to kill the Amalekites the same way Hitler asked his soldiers to kill the Semites? Does Holy Ghost fire pursue people the same way Police pursue criminals?

The ambiguity in meaning with respect to answers to the above questions constitutes what is known as religious problem. The problem of religious language started with the practitioners of the Abrahamic religious tradition-Judaism, Islam and Christianity. All three faiths proclaim truth about God in written texts, commentary traditions and oral teachings. Since God is thought to be incorporeal, finite, and timeless the predicate applied to corporeal, finite, temporal creatures would not apply to them. This problem is a philosophical one that has engaged the attention of scholars since years.

Multiple solutions have been suggested and defended over time. Four of these will be briefly mentioned. The first solution suggests that all statement about god is meaningless. Many scholars including Ayer (143) maintained this view. He posited that since assertions about God cannot be empirically verified that they are therefore meaningless.

The second solution suggests that all attributes predicated of god are to be interpreted equivocally, with respect to what they mean in reference to creatures. 
Consequently, this solution would argue that god is not good in the same sense Mother Theresa was; god's goodness is entirely different from the goodness of a creature. However, god can be spoken of by human beings only through negations.

The third solution suggests that the attributes predicated of god are to be interpreted univocally. A modern proponent of this view is Alton (220). He argues that a human being can know something and god can know that same fact. But how god knows something will be different from the way that a human being knows in so far as god incorporeal omniscient etc.

The fourth solution suggests that the attributes predicated of god are to be interpreted analogously. For instance, when the predicate good is applied to God, good refers to the unity that is god's essence and not an individual feature of God. This approach provides a middle position between an equivocal and a univocal solutions, since terms used analogously are not entirely equivocal nor are they entirely univocal: terms used analogously signify the same thing but in different modes (Aquinas).

The above suggested historical solutions to the problem of religious language are based on the claim of the $20^{\text {th }}$ century logical positions that unless a statement can at least in theory be empirically verified by scientific testing, it is meaningless. With the exception of the one stating that religious statements are meaningless, the other three historical solutions offer a way in which statements about God and afterlife might be understood.

Nevertheless, many other ways of approaching the problem of religious language are still emerging. Different people have different standards for verifying statements. What counts for one may not count for another because not everyone has the same blik. A blik, according to Hare in 
Lafave, is a frame of reference in terms of which data is interpreted - a mental filter in terms of which the notions of evidence is defined. Without a blik there can be no explanation; for it is by our bliks that we decide what is and what is not an explanation. Religious people have a religious blik. Once one accepts the religious blik, one has a brand new way of looking at the world. One's frame of reference is radically altered, and with it, one's evidentiary standards. Suddenly all sorts of things that previously did not count as evidence for God begins to count then one's evidentiary filter becomes so obvious that nothing can falsify it.

Religion is a matter of being intellectually convinced of the truth of certain propositions. The truth is not always cutand dried; we may be more or less convinced that a claim is reasonable to believe; and we might reasonably believe claims whose truth is objectively unknown.

In as much as faith keeps religious statements valid, its one vital problem should be pointed out. Scientific statements make assertions about the world and then challenge us to prove it to be untrue. Religious statements do not assert any tangible thing that can be held (Stangroom). The statement "God watches over me" cannot be falsified especially in the light of another statement that God is invisible. if the speaker gets run down by a bus, that might suggest that god was distracted momentarily, even at that a believer would retort that it was part of God's plan that a person gets flattened by a bus. The point is that nothing is allowed to count against the belief expressed in the statement that "God is watching over me".

No matter how the argument goes, the statement still has a meaning without being factual. Believing that god watches over believers as expressed in the above statement is the right theology in Biblical faith. Statements that affect a person's life have meaning for the person affected. Religion is a 
question of relationship and it is not unreasonable or illogical to maintain faith in a person with whom one has a relationship. Religious adherents often admit that some statements can be falsified by conflicting evidence but that faith in God's unverifiable plan is of greater validity. The problem of evil, for instance, is just real for a believer as well as for an unbeliever. There is no other solution for the believer other than faith.

Suffice it to say that neither falsification nor verification provides an adequate criterion for establishing meaning. Other ways of understanding religious language including the use of simile, for example, "God is like a watchmaker". One can picture a watchmaker making his device and getting it tick away nicely and can extract from that an image of God creating the world and getting it rolling.

Metaphor is also frequently used in religious language, such as "the promised land is flowing with milk and honey". Unlike simile, we are not saying that Canaan is like milk and honey; rather the image conjured up is an association of sweetness, warmth, security, plenty, and all other good things. There is a danger, however, in saying that all talk about God is metaphorical for there is an element of untruth about metaphors. Just like the above statement about Canaan. It turned out to be the opposite. Isrealites encountered much suffering there. At no time did they experience peace there up till modern times, but this does not in any way jeopardize God's promise and its fulfillment that must surely be realized at the fullness of time.

Religious language nowadays is based on outside experience. It is in fact becoming part of our experiences. Believers strongly rely on faith which remains unshaken in the face of worldly evidence (Windsor). Language is never meaningless, so long as the interlocutors understand the concept behind what they are communicating on. The value 
of any statement therefore is based on its pragmatic value of the proponent. Pragmatics, describes how the linguistic features of utterances are related to the communication situation, (Austin, 62) Also in Austin's speech act which insists on how to use language to do things. This invariably applies to religious issues. For instance, when one says "God is love", one is simply confirming and sharing one's belief in God intrinsically loving nature. If one says "Killing is wrong", one is simply sharing and confirming one's own moral principle and hence the statement has meaning and action of faith can emanate as a result. These statements may not have objective value but they have religious meaning or value.

Those within a faith community have their own way of using languages; their own religious language can only really be understood by being a part of the language game. Religious language derives its meaning from the fact that while its concepts may not clearly describe objects in the world the way they are, they do have a set of definition which is accepted by its users. In this way, religious language can be seen as adapting to how the view of the world changes.

Finally, it is important to note that faith communities of different types are in excess in our society hence the multiplicity of religious languages. The ultimate requirement of these faiths is that the cult which is expressed in religious language should always correspond with the conduct of the members in order to achieve the expected eternal bliss. But while faith-talk or God-talk increases, the accompanying moral commitment it is supposed to engender is conspicuously missing. Faith expression in words without translation into action is hollow religiosity. Real faith based actions as expressed in religious language are the needed magical tools that can pull down the frontiers or barriers of 
misunderstanding and doubt embedded in deciphering the objective value and meaning of religious language.

\section{Conclusion}

The problem of religious language has been an age long one. While no single solution among the historical approaches has emerged to the satisfaction of all religious communities or philosophers of religion all provide clues about how God might be understood.

In contemporary times attention has shifted to how such statements could be verified or falsified scientifically. Real life experiences show belief or faith to be a reality. Therefore, its expression which essentially must contain predicate about God and his nature, as a matter of fact, should have meaning at least to the group of people who use such language.

The essence of using a language is to communicate. Religious languages communicate and express ideas, emotions and convictions to faith audience. It is the medium for the transmission of religious ideas between faith members. The end purpose of this expression and communication of religious ideas and emotions is to elicit acts that are similar to what is expressed and communicated in order to gain eternal

life. This is why the expression of religious language, together with its meaning could be linguistically okay but religiously incomplete without the accompanying religiousbehavioral commitment. 


\section{References}

Alston, W.P. "Religious Language" in The Oxford Handbook of Philosophy of Religion. W.J. Wainwright(Ed):Oxford University Press,2020-44.2005.

Aquinas, S.T. Summa Theological. Translated by fathers of the English Dominican Pronvince. New York: Benziger Bros, 1948.

Ayer, A.J, "God-Talk is Evidently Nonsense" in Philosophy of Religion. Brian Davies(Ed).Oxford University Press 143-147,2000.

Bhatia, Vikay. K. Analysing Genre: Language use in Professional Settings. Longman group, UK Ltd,1993.

Buswel, R.E.(Ed). Encyclopedia of Buddhism.Vol.1. London: Macmillan. P137.2003.

Campbell, A. Religion and Language. Retrieved $1^{\text {st }}$ June, 2009.htt://www.acampbell.ukfsn.org/essays/skeptic/lan guage.htm.

Crapo.H. Anthropology of Religion: The Unity and Diversity of Religions.New York: McGraw-Hill Comp.Inc, 2002. 